九州大学学術情報リポジトリ

Kyushu University Institutional Repository

Studies on the Trisomics in Rice Plants (Oryza sativa L.) : VII. Some Marker Genes Located on Chromosome 2 and Their Sequence on the Linkage Map

Iwata, Nobuo

Plant Breeding Laboratory, Faculty of Agriculture, Kyushu University

Satoh, Hikaru

Plant Breeding Laboratory, Faculty of Agriculture, Kyushu University

Omura, Takeshi

Plant Breeding Laboratory, Faculty of Agriculture, Kyushu University

https://doi.org/10.5109/23800

出版情報 : 九州大学大学院農学研究院紀要. 29 (2/3)，pp. 139-144，1984-12. Kyushu University バージョン：

権利関係 : 


\title{
Studies on the Trisomics in Rice Plants (Oryza sativa L.) VII. Some Marker Genes Located on Chromosome 2 and Their Sequence on the Linkage Map
}

\author{
Nobuo Iwata, Hikaru Satoh and Takeshi Omura \\ Plant Breeding Laboratory, Faculty of Agriculture, \\ Kyushu University, Fukuoka 812, Japan \\ (Received September 28, 1984)
}

\begin{abstract}
Using trisomic method, some genes located on chromosome 2 were detected, and their gene sequence on the chromosome was inferred.

A single recessive gene for a bright green leaf mutant, $b g l$, was newly described in this report.
\end{abstract}

\section{INTRODUCTION}

Nagao and Takahashi (1963) tentatively proposed twelve linkage groups which corresponded to a haploid chromosome number of rice $(n=12)$.

By the use of trisomic method, Iwata and Omura (1976) suggested a possibility that three linkage groups VI, IX and XII were located on the same chromosome, chromosome 2, which is the extra chromosome of trisomic type L.

By the use of reciprocal translocations involving chromosome 2, Sato et al. (1982) found the linkage relations between nl-I, a marker gene of linkage group IX, and both $d-l$ and gl-I, marker genes of linkage groups VI and XII, respectively.

Yoshimura et al. (1982) also confirmed by the reciprocal translocation method that $d$-l, marker gene of linkage group VI, and nl-I and ri, marker genes of IX, were located together on chromosome 2 .

In the present study, a new marker gene located on chromosome 2 was found by trisomic analysis, and a sequence of genes on chromosome 2 was inferred.

\section{MATERIALS AND METHOD}

Marker genes used in this study were $d-l$, nl-2 and ops of linkage group VI, al-K-2, al-K-3, $n l-1, r i$, spl-7 and $s p l-8$ of linkage group IX, gl-1 of linkage group XII, and $b g l$ described newly in the study (Table 1). A mutant for bright green leaf was induced by treating fertilized egg cells with $\mathrm{N}$-methyl$\mathrm{N}$-nitrosourea (MNU) solution and designated as bgl. It was single recessive to the normal. Trisomic type L (Iwata et al., 1970) was used for the trisomic analysis to find the genes located on chromosome 2. Recombination values 
Table 1. List of marker genes used and their linkage groups.

\begin{tabular}{|c|c|c|c|}
\hline $\begin{array}{l}\text { Linkage }^{1)} \\
\text { group }\end{array}$ & $\begin{array}{l}\text { Gene } \\
\text { symbol }\end{array}$ & Character & Reference \\
\hline VI & $\begin{array}{l}\mathrm{d}-1 \\
\mathrm{nl}-2 \\
\text { ops }\end{array}$ & $\begin{array}{l}\text { daikoku dwarf } \\
\text { neck leaf } 2 \\
\text { open spikelet sterile }\end{array}$ & $\begin{array}{c}\text { Nagao and Takahashi (1963) } \\
\text { Iwata and Omura (1977) } \\
\text { " }\end{array}$ \\
\hline IX & $\begin{array}{l}a l-K-2 \\
a l-K-3 \\
n l-1 \\
r i \\
s p l-7 \\
s p l-8\end{array}$ & $\begin{array}{l}\text { albino Kyushu } 2 \\
\text { albino Kuyshu } 3 \\
\text { neck leaf } 1 \\
\text { verticillate rachis } \\
\text { spotted leaf } 7 \\
\text { spotted leaf } 8\end{array}$ & $\begin{array}{l}\text { Iwata and Omura (1978) } \\
\text { Nagao and Takahashi (1963) } \\
\text { Iwata et al. (1978) } \\
\text { " }\end{array}$ \\
\hline \multirow[t]{2}{*}{ XII } & $g l-I$ & glabrous leaf and hull 1 & Nagao and Takahashi (1963) \\
\hline & $b g l$ & bright green leaf & \\
\hline
\end{tabular}

1) By Nagao and Takahashi (1963)

2) Although the standardization of gene symbols in rice has been discussed and new symbols are recommended for some genes by Japanese Committee on Nomenclature and Linkage Group of Rice, original symbols are used in this study to avoid the confusion, because the symbols recommended are still not authorized.

were calculated in $F_{2}$ and $F_{3}$ by the mehtod of maximum likelihood.

\section{RESULTS AND DISCUSSION}

Segregation of marker genes in $\mathrm{F}_{2}$ of the crosses with trisomic type $\mathrm{L}$ were shown in Table 2. Three marker genes of linkage group VI, d-l, $n l-2$ and ops, two of IX, nl-I and ri, and one of XII, gl-1, showed the trisomic segregation. Regarding $b g l$, the segregation mode of dominant 63: recessive 1 was observed in the $F_{2}$ with type $L$ and it was also considered to be the trisomic segregation. It is reasonably expected, therefore, that these seven genes compose a linkage group located on chromosome 2.

Linkage relations were observed between $b g l$ and some marker genes belonging to linkage groups VI and IX (Table 3). From $F_{2}$ and $F_{3}$ data, the weighted means of recombination values on $b g l-d-1, b g l-o p s, b g l-r i, b g l-s p l-7$ and $b \mathrm{gl}-\mathrm{spl}-8$ were estimated at $34.2 \%, 12.6 \%, 2.9 \%, 16.1 \%$ and $15.4 \%$, respectively. These facts show that the $b g l$ links closely with $r i$ of linkage group IX and also links with both $d-l$ and ops of linkage group VI. It is obvious, therefore, that both linkage groups VI and IX which have been proposed by Nagao and Takahashi (1963) are combined in one group through the $b g l$ gene.

The linkage relations among some marker genes belonging to the linkage groups VI or IX were investigated (Table 4). Recombination values of $n l-2-$ $d-I, n l-2$-ops and $d-I$-ops were estimated at $22.3 \%, 44.0 \%$ and $30.7 \%$, respectively, suggesting a sequence of $n l-2-d-1-o p s$.

A recombination value of $s p l-8-s p l-7$ was $29.6 \%$. From this linkage intensity and the linkage intensities of $b g l-s p l-7$ (16.1\%) and $b g l-s p l-8(15.4 \%)$ men- 
Table 2. Trisomic segregation of the marker genes belonging to three linkage groups and of a marker gene described newly, in $\mathrm{F}_{2}$ of crosses with trisomic type L.

\begin{tabular}{|c|c|c|c|c|c|}
\hline \multirow{2}{*}{$\begin{array}{l}\text { Linkage } \\
\text { group }\end{array}$} & \multirow{2}{*}{ Gene } & \multicolumn{3}{|c|}{ Observed number } & \multirow{2}{*}{$\begin{array}{c}\chi^{2} \\
\text { for } 3: 1\end{array}$} \\
\hline & & Dominant & Recessive & Total & \\
\hline \multirow[t]{3}{*}{ VI } & $d-I$ & 390 & 48 & 438 & $46.05 * * *$ \\
\hline & nl-2 & 477 & 32 & 509 & $95.06 * * *$ \\
\hline & $o p s$ & 402 & 36 & 438 & $65.78^{* * * *}$ \\
\hline \multirow[t]{2}{*}{ IX } & $n l-1$ & 281 & 24 & 305 & 47. $74^{* * * *}$ \\
\hline & ri & 424 & 16 & 440 & $107.10 * * *$ \\
\hline \multirow[t]{2}{*}{ XII } & $\mathrm{gl}=1$ & 410 & 24 & 434 & $87.75 * * * *$ \\
\hline & $b g l$ & 63 & 1 & 64 & $18.75 * * *$ \\
\hline
\end{tabular}

***: Significant at $0.1 \%$ level.

These data are partially quoted from Iwata and Omura (1976).

Table 3. Linkage relations between $b g l$ and five genes belonging to the linkage groups $\mathrm{Vi}$ or IX.

\begin{tabular}{|c|c|c|c|c|c|c|}
\hline Gene pair & $\begin{array}{l}\text { Source } \\
\text { of } \\
\text { data }\end{array}$ & Phase ${ }^{11}$ & Segregation*) & Total & $\begin{array}{c}\text { Recombination } \\
\text { value } \\
(\%)\end{array}$ & $\begin{array}{l}\text { Weighted mean of } \\
\text { recombination } \\
\text { value }(\%)\end{array}$ \\
\hline \multirow[t]{3}{*}{$b g l-d-1$} & $\mathrm{~F}_{3}(\mathrm{Ab})$ & $\mathrm{R}$ & 326: $130: 115: 15$ & 586 & $34.7 \pm 3.6$ & \\
\hline & & $\mathrm{R}$ & 47: 41 & 88 & $30.4 \pm 4.5$ & \\
\hline & $\begin{array}{l}F_{3}(\mathrm{aB}) \\
-\mathrm{F}_{2}\end{array}$ & $\mathrm{R}$ & 37: 28 & 65 & $39.8 \pm 6.0$ & $34.2 \pm 2.5$ \\
\hline \multirow[t]{2}{*}{$b g l-o p s$} & $F_{3}(A b)$ & $\mathrm{R}$ & 108: 49: 42: 0 & 199 & $\doteqdot 0$ & \\
\hline & & $\mathrm{R}$ & 38: 11 & 49 & $12.6 \pm 3.8$ & \\
\hline \multirow[t]{3}{*}{$b g l-r i$} & $\mathrm{~F}_{3}(\mathrm{Ab})$ & $\mathrm{R}$ & 228: $91: 61: 0$ & 380 & $\div 0$ & \\
\hline & & $\mathrm{R}$ & 84: 4 & 88 & $2.3 \mathrm{f} 1.2$ & \\
\hline & $\mathrm{F}_{3}(\mathrm{aB})$ & $\mathrm{R}$ & 53: 5 & 58 & $4.5 \pm 2.0$ & $2.9 \pm 1.0$ \\
\hline \multirow[t]{3}{*}{$b g l-s p l-7$} & & $\mathrm{R}$ & 390: 194: 171: 5 & 760 & $16.5 \pm 3.5$ & \\
\hline & $\mathrm{F}_{3}(\mathrm{Ab})$ & $\mathrm{R}$ & 68: 23 & 91 & $14.5 \pm 3.0$ & \\
\hline & $F_{3}(a B)$ & $\mathrm{R}$ & 63: 27 & 90 & $17.6 \pm 3.3$ & $16.1 \pm 1.9$ \\
\hline \multirow[t]{2}{*}{$b g l-s p l-8$} & & $\mathrm{R}$ & 191: 94: 91: 3 & 379 & 17. $6 \mathrm{f} 4.9$ & \\
\hline & $\mathrm{F}_{3}(\mathrm{Ab})$ & $\mathrm{R}$ & $70: 24$ & 94 & $14.6 \pm 3.0$ & $15.4 \pm 2.5$ \\
\hline
\end{tabular}

1) $R=$ Repulsion phase

2) $\mathrm{F}_{2}=\mathrm{AB}: \mathrm{Ab}: \mathrm{aB}: \mathrm{ab}, \mathrm{F}_{3}(\mathrm{Ab})=\mathrm{AAbb}: \mathrm{A} a \mathrm{~b} b \cdot \mathrm{F}_{3}(\mathrm{aB})=\mathrm{a} a \mathrm{BB}: \mathrm{a} a \mathrm{Bb}$.

tioned before, the sequence of $s p l-8, s p l-7$ and bgl is considered as $s p l-7-b g l-$ spl-8.

Recombination values of $s p l-7-n l-1, r i-s p l-7$ and $r i-n l-1$ were estimated at $10.4 \%, 14.7 \%$ and $30.7 \%$, respectively. The sequence of the three genes, thus, should be $r i-s p l-7-n l-1$. The genes bgl and $r i$ linked closely (2.9\%) as mentioned above, therefore, a gene sequence of $s p l-8-b g l-r i-s p l-7-n l-1$ or $s p l-8-r i-b g l-s p l-7-n l-1$ is considered at this group. Moreover, based on the 
Table 4. Linkage relations among the marker genes belonging to the linkage groups VI or IX.

\begin{tabular}{|c|c|c|c|c|c|c|}
\hline Gene pair & $\begin{array}{l}\text { Source } \\
\text { of } \\
\text { data }\end{array}$ & Phase1) & Segregation ${ }^{2)}$ & Total & $\begin{array}{l}\text { Recombination } \\
\text { value } \\
(\%)\end{array}$ & $\begin{array}{c}\text { Weighted mean of } \\
\text { recombination } \\
\text { value }(\%)\end{array}$ \\
\hline$n l-2-d-l$ & $\mathrm{~F}_{2}$ & $\mathrm{R}$ & 398: 163: 194: 9 & 764 & $22.3 \pm 3.0$ & \\
\hline$n l-2$-ops & $\mathrm{F}_{2}$ & $\mathrm{R}$ & 212: 80: 77: 19 & 338 & $44.0 \pm 4.1$ & \\
\hline$d-1-o p s$ & $\begin{array}{l}\mathrm{F}_{2} \\
\mathrm{~F}_{2} \\
\mathrm{~F}_{3}(\mathrm{Ab})\end{array}$ & $R R$ & $\begin{array}{l}\text { 573: 142: } 127: 104 \\
\text { 294: 27: } 24 \text { 120: } 112: 2\end{array}$ & $\begin{array}{r}946 \\
52851 \\
\end{array}$ & $\begin{array}{l}34.1 \pm 2.0 \\
30.8 \pm 6.014 .8 \pm 4.2\end{array}$ & $30.7 \mathrm{f} 1.7$ \\
\hline$d-1-s p l-7$ & $\mathrm{~F}_{2}$ & $\mathrm{R}$ & 106: 47: 41: 9 & 203 & 40. If 5.8 & \\
\hline$s p l-8-s p l-7$ & $\mathrm{~F}_{2}$ & $\begin{array}{l}\mathrm{C} \\
\mathrm{R}\end{array}$ & 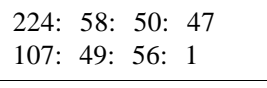 & $\begin{array}{l}379 \\
213 \\
\end{array}$ & $\begin{array}{l}33.0 \pm 3.1 \\
13.6 \pm 6.7\end{array}$ & $29.6 F 2.8$ \\
\hline$r i-s p l-7$ & $\begin{array}{l}\mathrm{F}_{2} \\
\mathrm{~F}_{3}(\mathrm{Ab}) \\
\mathrm{F}_{3}(\mathrm{aB})\end{array}$ & $\begin{array}{l}\mathrm{R} \\
\mathrm{R} \\
\mathrm{R}\end{array}$ & $\begin{array}{l}\text { 198: } 91: 98: 1 \\
\text { 53: } 14 \\
\text { 43: } 28\end{array}$ & $\begin{array}{r}388 \\
67 \\
71 \\
\end{array}$ & $\begin{array}{l}10.4 \pm 5.0 \\
11.7 \pm 3.1 \\
24.6 \pm 4.5\end{array}$ & 14. $7 \pm 2.3$ \\
\hline ri-nl-1 & $\begin{array}{l}F_{2} \\
F_{2}\end{array}$ & $\begin{array}{l}c \\
\mathrm{R}\end{array}$ & $\begin{array}{l}\text { 241: } 48: 45: 54 \\
220: 84: 93: 18\end{array}$ & $\begin{array}{l}388 \\
415 \\
\end{array}$ & $\begin{array}{l}27.3 \pm 2.7 \\
40.5 \pm 4.1\end{array}$ & $30.7 \pm 2.1$ \\
\hline$s p l-7-n l-1$ & $\begin{array}{l}\mathrm{F}_{2} \\
\mathrm{~F}_{3}(\mathrm{Ab}) \\
\mathrm{F}_{3}(\mathrm{aB})\end{array}$ & $\begin{array}{l}\mathrm{R} \\
\mathrm{R} \\
\mathrm{R}\end{array}$ & $\begin{array}{l}\text { 194: } 102: 92: 0 \\
\text { 34: } 11 \\
\text { 56: } 11\end{array}$ & $\begin{array}{r}-388 \\
45 \\
67 \\
\end{array}$ & $\begin{array}{r}0 \\
13.9 \pm 4.2 \\
8.9 \pm 2.7 \\
\end{array}$ & $10.4 \pm 2.3$ \\
\hline
\end{tabular}

1) $R=$ Repulsion phase. $C=$ Coupling phase.

2) $F_{2}=A B: A b: a B: a b . F_{3}(A b)=A A b b: A a b b . F_{3}(a B)=a a B B: a a B b$.

Table 5. Linkage relations between two albino genes belonging to the linkage group IX and three marker genes locating on chromosome 2 .

\begin{tabular}{|c|c|c|c|c|c|c|}
\hline Gene & $\begin{array}{l}\text { Source } \\
\text { of } \\
\text { data }\end{array}$ & Phase & Segregation') & Total & $\begin{array}{c}\text { Recombination } \\
\text { value } \\
(\%)\end{array}$ & $\begin{array}{c}\text { Weighted mean of } \\
\text { recombination } \\
\text { value }(\%)\end{array}$ \\
\hline$a l-K-2-s p l-7$ & $\begin{array}{l}F_{a}(A b) \\
F_{3}(A B)\end{array}$ & $\begin{array}{l}\mathrm{R} \\
\mathrm{R}\end{array}$ & $\begin{array}{ll}\text { 52: } & 14 \\
\text { 17: } & 107\end{array}$ & $\begin{array}{r}66 \\
124\end{array}$ & $\begin{array}{l}11.9 \pm 3.1 \\
15.0 \pm 3.8\end{array}$ & $13.1 \pm 2.4$ \\
\hline$a l-K-3-n l-2$ & $\begin{array}{l}F_{3}(A b) \\
F_{3}(A B)\end{array}$ & $\begin{array}{l}\mathrm{R} \\
\mathrm{R}\end{array}$ & $\begin{array}{ll}46: & 51 \\
26: & 90\end{array}$ & $\begin{array}{r}97 \\
116\end{array}$ & $\begin{array}{l}35.7 \mathrm{f} 4.7 \\
26.8 \pm 6.0\end{array}$ & $32.3 \pm 3.7$ \\
\hline$a l-K-3-d-l$ & $\begin{array}{l}\mathrm{F}_{3}(\mathrm{Ab}) \\
\mathrm{F}_{3}(\mathrm{AB})\end{array}$ & $\begin{array}{l}\mathrm{R} \\
\mathrm{R}\end{array}$ & $\begin{array}{ll}91: & 38 \\
52: & 170\end{array}$ & $\begin{array}{l}129 \\
222\end{array}$ & $\begin{array}{l}17.3 \pm 2.3 \\
28.4 \pm 4.6\end{array}$ & $20.2 \pm 2.4$ \\
\hline
\end{tabular}

1) $F_{3}(A b)=A A b b: A a b b . F_{3}(A B)=A A B_{-}: A_{a B}$.

linkage intensities of $b g l-d-1$ (34.299, $b g l-o p s(12.6 \%), d-1-s p l-7$ (40.1\%) and so on in Table 3 or 4 , the gene sequence of d-I-spl-S-ops-bgl-spl-7 was tentatively proposed, although a three point analysis was essential to get the exact order of these genes on the map.

Two albino genes, $\boldsymbol{a l - K - 2}$ and al-K-3, which linked to $n l-1$ with recombination values of $1.1 \%$ and $34.6 \%$ respectively have been reported by Iwata and 
Omura (1978). In the present study, the linkage relations between the albino genes and some marker genes located on chromosome 2 were observed (Table 5). Weighted mean of recombination values of $a l-K-2-s p l-7$ was estimated at $13.1 \%$ and a gene sequence of either $s p l-7-n l-1-a l-K-2$ or $s p l-7-a l-K-2$ $-n l-1$ is considered. The $a l-K-3$ was linked to nl-2 and $d-I$ with the recombination values of at $32.3 \%$ and $20.2 \%$, respectively, suggesting the gene sequence of $n l-2-d-I-a l-K-3$. The gene arrangement of $a l-K-3$ and $s p l-8$ at the map may be expected as $d-I-a l-K-3-s p l-8-\& l$, however, further investigation will be necessary to confirm it.

Based on the results of the present study, the sequence of the ten genes on the chromosome 2 can be drawn tentatively as shown in Fig. 1.

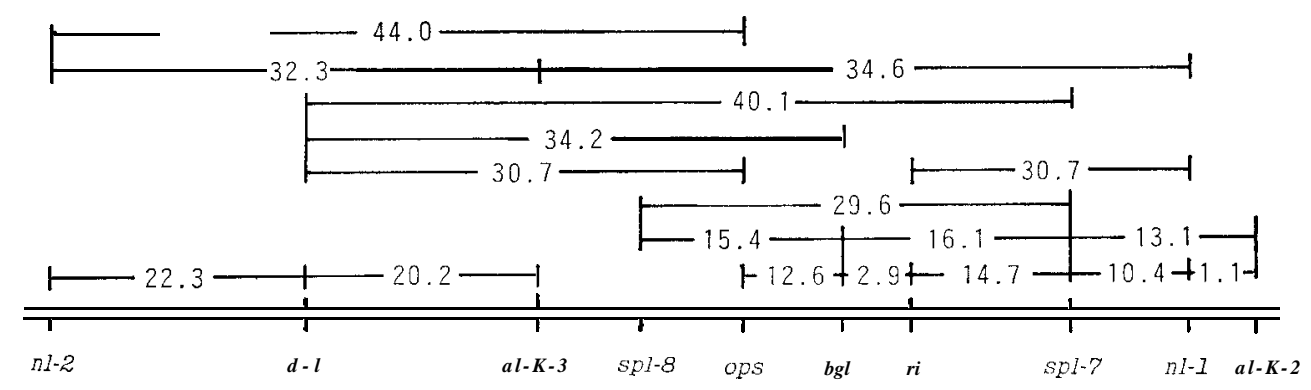

Fig. 1. A linkage map of 10 genes on chromosome 2

Thus, the linkage group corresponded to the chromosome 2 was reconstructed with the marker genes of the two linkage groups which have been proposed tentatively by Nagao and Takahashi (1963).

Sato et al. (1982) estimated the gene sequence of $d-I-n l-1-g l-I$ on the chromosome 2 from the facts that some interchanged points of reciprocal translocation lines involving chromosome 2 linked with both $d-l$ and $n l-1$, and others linked with both nl-I and $g l-1$. Although ten genes were found to locate on the chromosome 2 in the present paper, none of the linkage relations between these genes and $g l-I$ were found. To find out the genes linked with $g l-1$, trisomic analysis of mutant lines has been conducting by the use of type L.

\section{REFERENCES}

Iwata, N. and T. Omura 1971 Linkage analysis by reciprocal translocation method in rice plants (O ryza sativa L.). I. Linkage groups corresponding to the chromosome 1, 2, 3 and 4. Japan. J. Breed., 21: 19-28 (in Japanese with English summary)

Iwata, N. and T. Omura 1976 Studies on the trisomics in rice plants (Oryza sativa L.). IV. On the possibility of association of three linkage groups with one chromosome. Japan. J. Genet., 51: 135-137

Iwata, N. and T. Omura 1977 Linkage studies in rice (Oryza sativa L.). On some mutants derived from chronic gamma irradiation. J. Fuc. Agr., KyushuUniv., 21: 117-127 
Iwata, N. and T. Omura 1978 Linkage studise in rice (Oryza sativa L.). Some albino genes and their linkage relations with marker genes. Sci. Bull. Fac. Agr., Kyushu Univ., 33: 11-18 (in Japanese with English summary)

Iwata, N., T. Omura and M. Nakagahra 1970 Studies on the trisomics in rice plants (Oryza sativa L.). I. Morphological classification of trisomics. Japan. J. Breed., 20: 230-236

Iwata, N., T. Omura and H. Satoh 1978 Linkage studies in rice (Oryza sativa L.). On some mutants for physiological leaf spots. J.Fac. Agr., Kyushu Univ., 22: 243-251

Nagao, S. and M. Takahashi 1963 Trial construction of twelve linkage groups in Japanese rice. Genetical studies on rice plants, XXVII. J. Fac. Agr., Hokkaido U niv., 53: 72130

Sato, S., K. Muraoka and Y. Sano 1982 Reconstruction of a linkage group corresponding to the Nishimura's second chromosome in rice, Oryza sativa L. Japan.J. Breed., 32: 232-238

Yoshimura, A., N. Iwata and T. Omura 1982 Linkage analysis by reciprocal translocation method in rice plants (Oryza sativa L.). III. Marker genes located on chromosomes 2, 3, 4 and 7. Japan. J. Breed., 32: 323-332 